\section{Forced-Molting Methods and Their Effects on the Performance and Egg Quality of Japanese Quails (Coturnix japonica) in the Second Laying Cycle}

\section{ABSTRACT}

The experiment was carried out in the experimental poultry house of the Research and Development Unit of Brotas of Agência Paulista de Tecnologia dos Agronegócios do Centro-Oeste, SP, Brazil. The objective of the study was to evaluate the performance of Japanese quails submitted to forced molting aiming at optimizing the use of the same quail flock by promoting a second laying cycle. A total number of 400 67-day-old Japanese quails in lay, previously submitted to 14 days of forced molting, was distributed in a completely randomized experimental design into five treatments $(T 1=$ not submitted to forced molting, $\mathrm{T} 2=$ 03 days of fasting + fed ad libitum, $\mathrm{T3}=01$ days of fasting +13 days of feed restriction, $T 4=02$ days of fasting +12 days of feed restriction, and $\mathrm{T} 5=03$ days of fasting +11 days of feed restriction. Feeds were contained equal nutrient levels, and were formulated according to NRC (1994) recommendations. There were significant differences among the studied treatments. Although the treatment of 3 days of fasting followed by ad libitum feeding resulted in lower egg weight, it promoted better lay percentage, egg mass, and feed conversion ratios (FCR/dz and FCR/ $\mathrm{kg}$ ). On the other hand, 3 days of fasting followed by restricted feeding resulted in higher feed intake and worse feed conversion ratios (FCR/dz and $F(R / \mathrm{kg}$ ). When birds were not submitted to forced molting, they presented lower lay percentage and egg mass.

\section{INTRODUCTION}

Molting or renewal of feathers in wild birds is a natural process, which occurs to maintain bird's flying capacity and to protect them from weather conditions. Cessation of egg production and beginning of molting are indication that the bird's physical conditions are deteriorating, making them incapable of supporting egg production, as well as feather and body maintenance (Ellis, 2000).

The technique of forced molting of layer hens, with the purpose of using them for one extra production cycle, was initially used in the EUA in the 1960s. Today, several methods have been studied. In practice, management methods are the most commonly used, and there are many techniques recommended by different research centers, which makes their comparison difficult (Castelo Llobet et al., 1989).

Quails present early sexual maturity and long egg-production cycle; however, there is currently a high demand for day-old quails, which has caused prolonged use of laying flocks (Garcia, 2001). Under these conditions, the use of forced molting may be an interesting option.

In commercial layer hen production, forced molting is a planned technique of bird replacement, aiming at reducing costs with of buying replacement pullets and optimizing the use of the facilities. This practice has been increasingly used in commercial farms to extend laying period, 
Faitarone ABG, Garcia EA, Pizzolante CC, Molino AB, Pelícia $\mathrm{K}$, Berto DA

with the purpose of making the bird's reproductive system rest for a period shorter than the natural period in order to restore reproductive capacity, improve eggshell quality and to reduce losses (Ramos et al., 1999).

The decision of using a forced molting program depends on several factors, such as: replacement pullet price, end-of-lay layer meat price, flock egg production, egg quality and weight expected for the second cycle, egg price, feed cost, maximum facility use, planned replacement programs, and employed molting method (Garcia, 2001).

The forced molting methods conventionally used for commercial layers can be classified in three groups: use of drugs, such as progesterone and chlormadinone; nutritional, which change the concentration of determined ions in the feed, such as calcium and phosphorus, sodium and potassium, iodine or zinc; and a wide range of management methods, which are the most frequently used (Castelo Llobet et al., 1989).

Several methods have been studied in the last three decades, but fasting, i.e., withdrawal of feed and/or water, along with artificial lighting suspension, is the most commonly applied (Wakeling, 1977; Shippee et al., 1979; Stevenson \& Jackson, 1984; Berry \& Brake, 1985; Harms, 1991), as it is easy to apply and promotes good results. However, although during natural molting feed intake, activity, and body weight are reduced, the method of extended feed withdrawal is considered harmful to bird welfare.

There is an increasing concern in researching alternative methods that reduce stress and present the same economic results as the conventional method applied in forced molting (Ramos et al., 1999).

According to EU directives, despite being economically favorable, all forced molting methods that restrict feed intake - either through fasting or the use of higher or lower levels of some minerals - impair bird welfare, and techniques that take into account bird welfare must be used. However, these techniques are expensive and time-consuming, as the period of body weight loss and reproductive function reduction are longer.

The first forced molting experiments with layer quail were carried out by Cantor \& Johnson (1984), who observed high body weight loss and mortality in the molted birds.

Zamprônio et al. (1996) did not observe beneficial effects of forced molting through feed and water fasting on the performance and egg quality of layer quails.
Forced-Molting Methods and Their Effects on the Performance and Egg Quality of Japanese Quails (Coturnix japonica) in the Second Laying Cycle
The technique of forced molting of Japanese quails was also studied by Garcia (2001), who found that feed fasting for three consecutive days caused $25.64 \%$ body weight loss, but promoted good performance during the second laying cycle. The supply of a production feed in the post-molting period resulted in higher initial egg production as compared to ground corn, but final egg production was affected by the type of feed used during the resting period.

If proper forced molting techniques could be used in quails, the reutilization of flocks in a new laying cycle could become an economically feasible alternative for quail egg production.

The present study aimed at evaluating the performance and the egg quality of Japanese quails submitted to alternative forced molting methods.

\section{MATERIAL AND METHODS}

The experiment was carried out in the experimental poultry house of the Research and Development Unit of Brotas of Agência Paulista de Tecnologia dos Agronegócios do Centro-Oeste, SP, Brazil, from September, 2005 to January, 2006.

A total number of 400 ed-of-lay female Japanese quails (Coturnix japonica). Birds were 65 weeks old in the beginning of the experiment.

Birds were housed in 4-m wide and 12-m long masonry poultry house. Twenty $100-\mathrm{cm}$ long, 34-cm wide, and $16-\mathrm{cm}$ high metal cages, with four internal divisions of $25 \mathrm{~cm}$ each, were used to house 20 birds per cage. Each cage compartment was equipped with a nipple drinker and a trough feeder placed in front of the cage.

The experimental period was 126 days. During the first 14 days, forced molting was applied with natural lighting, and the remaining 112 days were divided in four 28-day periods, when performance data were collected.

Birds were distributed in a completely randomized experimental design, with five treatments (forced molting methods), with four replicates of 20 birds each. The experimental treatments are shown in Table 1.

The experimental feed was based on ground corn and soybean meal, and formulated according to NRC (1994) recommendations.

During the forced molting period, birds were fed according to the treatments described above. Water was offered ad libitum. After forced molting, feed residues were weighed at the end of the four consecutive 28-day periods to estimate feed intake, 
Faitarone ABG, Garcia EA, Pizzolante CC, Molino AB, Pelícia $\mathrm{K}$, Berto DA

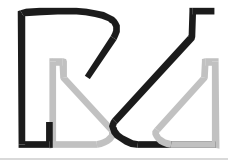

Forced-Molting Methods and Their Effects on the Performance and Egg Quality of Japanese Quails (Coturnix japonica) in the Second Laying Cycle and data were recorded in a specific form. Eggs were daily collected, and data were also recorded in a specific form. Eggs from each replicate were weekly counted and weighed. Every 28 days and for three consecutive days, four eggs per replicate were collected for egg-quality analyses.

\begin{tabular}{cl}
\hline $\begin{array}{c}\text { Table 1 - Experimental treatments. } \\
\text { Treatment }\end{array}$ & $\begin{array}{l}\text { Description } \\
\text { Birds that were not submitted to forced } \\
\text { molting }\end{array}$ \\
T2 & $\begin{array}{l}\text { Birds submitted to } 03 \text { days of fasting and then } \\
\text { fed ad libitum }\end{array}$ \\
T3 & $\begin{array}{l}\text { Birds submitted to } 01 \text { day of fasting, and then } \\
\text { restricted-fed }(15 \mathrm{~g} / \mathrm{bird} / \text { day) for } 13 \text { days }\end{array}$ \\
T4 & $\begin{array}{l}\text { Birds submitted to } 02 \text { days of fasting, and then } \\
\text { restricted-fed }(15 \mathrm{~g} / \mathrm{bird} / \text { day) for } 12 \text { days } \\
\text { Birds submitted to } 03 \text { days of fasting, and then } \\
\text { restricted-fed }(15 \mathrm{~g} / \mathrm{bird} / \text { day) for } 11 \text { days }\end{array}$ \\
\hline
\end{tabular}

During the four post-molting periods, birds were submitted to a lighting program of 17 hours of light daily, and feed was offered ad libitum. The following parameters were evaluated: live weight change, feed intake, egg production, mean egg weight, egg mass, feed conversion ratio (per $\mathrm{kg}$ and per dozen eggs), mortality, egg specific gravity, eggshell thickness, and yolk, albumen, and eggshell percentages.

Data were submitted to analysis of variance using SAS (2000) statistical package. Means were compared by the test of Tukey $(p<0.05)$.

\section{RESULTS AND DISCUSSION}

Table 2 shows egg weight, lay percentage, egg mass, feed intake, feed conversion ratio per dozen eggs, feed conversion ratio per kg egg, and mortality results of Japanese quails during the laying period after being submitted to forced molting.

Treatments significantly influenced all performance parameters, except mortality ( $p>0.05)$.

Egg weight in treatment 5 ( 3 days of fasting and restricted feeding) was higher as compared to treatments 2 ( 3 days of fasting and ad libitum feeding) and 3 ( 1 day of fasting and restricted feeding), whereas the other treatments were not significantly different from the above mentioned treatments.

The highest lay percentage was obtained in treatment 2 ( 3 days of fasting and ad libitum feeding), and the lowest in treatment 1 (control). The other treatments were not different from treatments 1 and 2 , or among themselves.

The highest egg mass was produced by birds in treatment 2 ( 3 days of fasting and ad libitum feeding) due to their higher lay percentage, whereas the lowest egg mass was produced by treatment 1 (control), also because of its low lay percentage. The other treatments did not influence this parameter.

The highest feed intakes were recorded for birds in treatments 4 ( 2 days of fasting and restricted feeding) and 5 ( 3 days of fasting and restricted feeding) as compared to treatment 3 ( 1 day of fasting and restricted feeding) because birds in treatments 4 and 5 were submitted to longer fasting periods and associated to subsequent feed restriction.

The worst feed conversion ratio per dozen eggs was observed in treatment 5 ( 3 days of fasting and restricted feeding) as compared to treatments 2 ( 3 days of fasting and ad libitum feeding) and 3 (1 day of fasting and restricted feeding). This worse feed conversion ratio of treatment 5 ( 3 days of fasting and restricted feeding) was due to the low egg production and the high feed intake presented by the birds submitted to this treatment. The other treatments did not affect this parameter.

Treatment 5 ( 3 days of fasting and restricted feeding) presented the worst feed conversion ratio per egg mass, whereas birds in treatment 2 ( 3 days of fasting and ad libitum feeding) had the best feed conversion ratio per egg mass due to its high lay percentage and moderate feed intake. There was no influence of the remaining treatments on this parameter.

There were no significant effects of treatments on mortality rate during lay. Average mortality rate during the 112 days of the laying cycle was $1.55 \%$, or $0.39 \%$ per month, which was similar to that observed during the first laying cycle.

The higher productivity observed in treatment 2 ( 3 days of fasting and ad libitum feeding) may be explained by the use of feed after fasting, allowing rapid body weight recovery, better development of the reproductive tract, and faster return of egg production, which is consistent with the results of Garcia (1994).

Cantor \& Johnson (1984) observed high body weight loss and mortality, and Zamprônio et al. (1996) did not detect beneficial results of the use of forced molting through feed and water fasting on layer quail performance and egg quality. Water fasting associated to feed fasting periods longer than three days used by those authors probably led to the observed high body weight loss, high mortality, and low performance. On the other hand, the performance results obtained in the present experiment are consistent with those 


\begin{tabular}{|c|c|c|c|c|c|c|c|}
\hline Treat. & $E W(g)$ & LP(\%) & EM(g) & $\mathrm{Fl}(\mathrm{g})$ & FCR $/ \mathrm{dz}$ & $\mathrm{FCR} / \mathrm{kg}$ & Mort.(\%) \\
\hline 1 & $10.59 a b$ & $68.96 \mathrm{~b}$ & $7.30 \mathrm{~b}$ & $21.80 a b$ & $0.39 a b$ & 3.07ab & 1.56 \\
\hline 2 & $10.41 b$ & $77.14 a$ & $8.03 a$ & 21.71ab & $0.35 b$ & $2.76 \mathrm{~b}$ & 1.56 \\
\hline 3 & $10.53 b$ & 72.84ab & 7.67ab & $21.18 b$ & $0.36 b$ & $2.84 a b$ & 1.26 \\
\hline 4 & 10.66ab & 73.42ab & 7.84ab & $22.98 a$ & $0.39 a b$ & $3.06 a b$ & 1.76 \\
\hline 5 & 10.86a & 70.76ab & 7.65ab & $22.69 a$ & $0.41 a$ & $3.15 a$ & 1.63 \\
\hline & $p<0.01$ & $p<0.05$ & $p<0.01$ & $p<0.01$ & $p<0.01$ & $p<0.05$ & $p>0.05$ \\
\hline CV (\%) & 4.21 & 12.22 & 12.92 & 7.72 & 17.90 & 15.85 & 132.04 \\
\hline
\end{tabular}

Means followed by different letters in the same column are significantly different by the test of Tukey $(p<0.05)$. T1 - Birds that were not submitted to forced molting. T2 - Birds submitted to 03 days of fasting and then fed ad libitum. T3 - Birds submitted to 01 day of fasting, and then restrictedfed (15g/bird/day) for 13 days. T4 - Birds submitted to 02 days of fasting, and then restricted-fed ( $15 \mathrm{~g} / \mathrm{bird} / \mathrm{day})$ for 12 days. T5 - Birds submitted to 03 days of fasting, and then restricted-fed (15g/bird/day) for 11 days.

observed by Garcia (2001), who suggested that the forced molting of quails through the application of feed fasting for three days, with approximately $25 \%$ weight loss, can promote good performance and low mortality.

Table 3 shows mean specific gravity, eggshell thickness $(\mathrm{mm})$, yolk percentage $(\%)$, albumen percentage (\%), and eggshell percentage (\%) results of Japanese quails during the laying period after being submitted to forced molting. It must be noted that there was no interaction between treatment and period on egg quality parameters.

Treatments significantly influenced specific gravity, eggshell thickness, and eggshell percentage. Yolk and albumen percentages were not affected $(p>0.05)$ by the experimental treatments.

The best egg gravities were recorded in treatments 4 ( 2 days of fasting and restricted feeding) and 5 ( 3 days of fasting and restricted feeding) as compared to treatment 1 (control). No effects of the other treatments were observed on this parameter.

Treatments 4 (2 days of fasting and restricted feeding) and 5 ( 3 days of fasting and restricted feeding) promoted the thickest eggshells as compared to treatment 2 (3 days of fasting and ad libitum feeding), which presented the thinnest eggshells due to the high egg production presented by the birds in this treatment.
Eggs from treatment 4 ( 2 days of fasting and restricted feeding) presented higher eggshell percentage as compared to treatments 2 ( 3 days of fasting and ad libitum feeding) and 3 ( 1 day of fasting and restricted feeding), which were not different from treatments 1 (control) and 5 (3 days of fasting and restricted feeding).

Ingram \& Herbert (1989), working with forced molting of commercial layer hens, found that feed restriction during post-fasting period did not significantly affect egg production or eggshell quality. Also, Garcia (1994) did not find any effect of feeding time and diet type during the post-fasting period on eggshell percentage; however, when birds were fed with ground corn for 10 days and laying feed thereafter, their eggshells were thicker than those of birds fed ground corn for only five days.

\section{CONCLUSIONS}

Under the conditions of the present experiment, we can conclude that ad libitum feeding after fasting promotes better initial egg production and laying persistence, as birds submitted to 3 days of fasting and subsequent ad libitum feeding presented the best postmolting performance. It is also concluded that if forced

\begin{tabular}{|c|c|c|c|c|c|}
\hline Treatments & SG & Eggshell thickness(mm) & Yolk(\%) & Albumen (\%) & Eggshell (\%) \\
\hline 1 & $1.073 b$ & $0.224 a b$ & 29.10 & 63.22 & $7.68 a b$ \\
\hline 2 & $1.074 a b$ & $0.213 c$ & 29.48 & 63.94 & $7.59 b$ \\
\hline 3 & $1.074 a b$ & $0.217 b c$ & 29.12 & 63.27 & $7.62 b$ \\
\hline 4 & $1.076 a$ & $0.227 a$ & 29.22 & 62.85 & $7.93 a$ \\
\hline \multirow[t]{2}{*}{5} & $1.076 a$ & $0.227 a$ & 29.68 & 62.48 & $7.85 a b$ \\
\hline & $p<0.01$ & $p<0.01$ & $p>0.05$ & $p>0.05$ & $p<0.01$ \\
\hline CV $(\%)$ & 0.37 & 6.95 & 6.30 & 3.02 & 5.78 \\
\hline
\end{tabular}

Means followed by different letters in the same column are significantly different by the test of Tukey ( $p<0.05)$. T1 - Birds that were not submitted to forced molting. T2 - Birds submitted to 03 days of fasting and then fed ad libitum. T3 - Birds submitted to 01 day of fasting, and then restrictedfed (15g/bird/day) for 13 days. T4 - Birds submitted to 02 days of fasting, and then restricted-fed (15g/bird/day) for 12 days. T5 - Birds submitted to 03 days of fasting, and then restricted-fed ( $15 \mathrm{~g} / \mathrm{bird} /$ day) for 11 days. 


\section{Faitarone ABG, Garcia EA, Pizzolante CC, Molino AB, Pelícia K, Berto DA}

Forced-Molting Methods and Their Effects on the Performance and Egg Quality of Japanese Quails (Coturnix japonica) in the Second Laying Cycle molting is not applied, there is low productivity. Birds not submitted to forced molting presented worse feed conversion ratios as compared to those submitted to this procedure.

\section{References}

Berry WD, Brake J. Comparison of parameters associated with molt induced by fasting, zinc and low dietary sodium in caged layers. Poultry Science 1985; 64:2027-2036.

Cantor $\mathrm{AH}$, Johnson EA. Inducing pauses in egg production of Japanese quail with dietary zinc. Poultry Science 1984; 63:10.

Castelo Llobet JA, Pontes M, Franco Gonzalez F. Produccion de huevos. Barcelona: Real Escuela de Avicultura; 1989.

Ellis MR. Moulting: a natural process; 2000. Available from: www.dpi.qdl.govg.au/poultry/5376.html.

Garcia EA. Avaliação dos parâmetros físicos e produtivos de poedeiras semi-pesadas submetidas à muda forçada e alimentadas com ração de baixa densidade por diferentes períodos (tese). Botucatu (SP):Faculdade de Medicina Veterinária e Zootecnia,Universidade Estadual Paulista; 1994.

Garcia EA, Mendes AA, Pizzolante CC, Veiga N. Aterações morfológicas e desempenho de codornas poedeiras tratadas com diferentes programas de alimentação no período de repouso da muda forçada. Revista Brasileira de Ciência Avícola 2001; 3:275282.

Garcia EA, Pizzolante CC. Muda forçada em poedeiras comerciais e codornas. Anais Conferência Apinco de Ciência e Tecnologia Avícola 2004; Campinas, São Paulo. BRA: Facta; 2004. p.45-62.
Harms RS. Effect of removing salt sodium or choride from the diet of commercial layers. Poultry Science 1991; 70:333-336.

Ingram DR, Herbert JA. Restricted feeding of second cycle White Leghorn hens. Nutrition Report International 1989; 39:397-203.

NRC - National Research Council Nutrient requirements of poultry. $9^{\text {th }}$ ed. Washington: National Academic Press; 1994.

Ramos RB, Fuentes MFF, Espíndola GB, Lima FAM, Freitas ER. Efeito de métodos de muda forçada sobre o desempenho de poedeiras comerciais. Revista Brasileira de Zootecnia 1999; 28(6):1340-1346.

SAS. SAS User's guide: statistics. $5^{\text {th }}$ ed. Cary, NC: SAS Institute; 2000.

Shippee RL, Stake PE, Kiehn U, Lambert JL, Simmons RW. High dietary zinc or magnesium as forced - resting agents for laying hens. Poultry Science 1979; 58:949-954.

Stevenson $\mathrm{MH}$, Jackson $\mathrm{N}$. Comparison of dietary hydrated copper sulfate, dietary zinc oxide and a direct method for inducing a moult in laying hens. Brazilian Poultry Science 1984; 25:505-517.

Wakeling DE. Induced molting - a review of the literature current practice and areas for further research. World's Poultry Science Journal 1977; 33:12-20.

Zamprônio EC, Moraes VMB, Malheiros RD. Efeitos da muda forçada sobre o desempenho produtivo e qualidade dos ovos em codornas (Coturnix coturnix japonica). Anais da Conferência Apinco de Ciência e Tecnologia Avícolas; 1996; Curitiba, PR. Campinas, São Paulo, BRA: FACTA; 1996. p.12. 
